\title{
Explain the Components of Urban Branding, Emphasizing the Dimensions of Tourism
}

\author{
Maryam Vahabian, ${ }^{1}$ Nowzar Ghanbari $\mathbb{D D}^{2}{ }^{2}$ Said Ali Nori, ${ }^{1}$ and Bizhan Kalhornia ${ }^{1}$ \\ ${ }^{1}$ Department of Architecture and Urban Planning, Kermanshah Branch, Islamic Azad University, Kermanshah, Iran \\ ${ }^{2}$ Department of Geography, Kermanshah Branch, Islamic Azad University, Kermanshah, Iran \\ Correspondence should be addressed to Nowzar Ghanbari; n.ghanbari@iauksh.ac.ir
}

Received 20 July 2021; Revised 5 August 2021; Accepted 26 August 2021; Published 8 November 2021

Academic Editor: S. Mahdi S. Kolbadi

Copyright ( $) 2021$ Maryam Vahabian et al. This is an open access article distributed under the Creative Commons Attribution License, which permits unrestricted use, distribution, and reproduction in any medium, provided the original work is properly cited.

\begin{abstract}
Currently, change in cities is advancing due to technological advances, information floods, increasing awareness, and raising living standards. Although the development of a city depends on the activation of urban marketing, an important and well-known city stands out as a brand. One of the strategies of urban management in order to progress in the competitive world market is to plan for sustainable urban branding for the city, which introducing the capabilities of the city, the most important factors in achieving economic benefits of urban branding are tourism and physical space. The metropolis of Hamadan has been selected for this purpose, including urban tourism destinations with historical and touristic species and the capital of Iran's history and civilization. The measurement tool in this study is a questionnaire that will be designed based on the conceptual framework of the research as well as related studies. For this purpose, the components and indicators of urban branding have been identified with emphasis on social, economic, cultural, and physical dimensions and have been used with the opinion of 30 urban experts and specialists and using SPSS25 software analysis at a significant level. It can be concluded that according to the respondents, these variables have a great impact on branding the metropolis of Hamadan.
\end{abstract}

\section{Introduction}

The cities and metropolises are now becoming more effective players than countries in geographical areas [1]. There is an increasing competition among cities, countries, and regions to attract tourists, investors, commercial and industrial companies, new citizens, and labour [2]. Therefore, the authorities and leaders of the cities have started branding their cities in order to increase the awareness about the cities as well as their attractions [3]. During the cultural competition, the rivalry among countries has increased the tendency toward public agencies, local offices, and residents in the urban cultures. Since the beginning of increasing interest in city branding or remarketing [4], the globalization occurred, particularly in large cities. The global changes of economy, culture, and politics have huge effects on renovation of cities around the world [5]. Place branding is designing a place in order to meet the needs of the target market of that place [6]. The success measure of place branding is the satisfaction of the citizens and business of the community as well as meeting the expectations of the visitors and investors [7]. Place branding is a strategy that gives it the unforgettable identity; it is a tool that can rapidly spread the values of a community [8]. Place and country branding should concern about this issue that how culture, history, economic growth, social development, infrastructure and architecture, landscape, and environment combine and provide an identity that is accepted by majority of people [9]. City branding is essential to develop policies of the city because it concerns the economic development, in the one hand, and acts as a conduit to identify the identity of the city, on the other hand.

According to the studies, the major problem of city development strategy (CDS) is the lack of a fundamental essential approach. Research about CDS has been done since the introduction of CDS as an important model for national policy $[10,11]$. Each city in the world enjoys a reputation regarding its capacities, facilities, and activities [12]. This is 
called city brand [13]: self-analysis, city of religions, and multidimensional city [14]. The main representations, implications, slogans, and other city branding methods have been discussed in the analysis of this process. This study tries to introduce city branding in Istanbul, using a historic approach [15]. Manourian et al. [9] designed a model for this purpose titled "The process model of urban branding for metropolises of Iran." In this research, city branding of Iran's metropolises and its features are studied, extracted, and presented in addition to causal and mediating conditions. The outcomes of city branding have studied in the metropolises of Iran [9]. In their study titled "The comparative study of global experiences of urban branding and provision of a solution for Mashhad City," Kharrazi et al. [16] admitted that this metropolis has special problems due to its geopolitical position, an important pilgrimages and tourism function, geographical position, and different economic structure. This city can achieve effective and stable brand by proper planning and management [16].

1.1. Theoretical and Conceptual Approach. As the cities around the world compete to attract tourists, investors, and talents to achieve their targets, the concept of brand enters from business into urban growth, renovation, and the quality of life [17]. If a city can achieve a positive mental image and stability, this reputation becomes a very valuable capital because it shows the capability of the city to continue the trade. Simply, the city with strong and positive mental image has a good reputation in the world and can attract capital, innovators, and tourists [18]. Today, brand is a strategic tool to harmonize the goals and plans of the city as well as the messages transferred by it [9] and Zenker and Rutter [19]. The definitions provided for branding are mentioned in Table 1.

We live in a world in which the branding culture is obviously seen in all human behaviors and places [25]. City branding is an issue that governments pay special attention to it now. The strategies used by different cities to achieve the financial, human, or tourist capitals are called city branding strategy [26]. A city with a strong brand will attract tourists, business, and investment and save the city in the crisis [27].

1.2. Brand and City Branding Literature Review. Various research studies have been done about city branding so far. A successful place branding creates value for the players and divisions that manage the city [28]. A key point about the destinations and places is that their position and values should originate from their innate realities and cultures [29]. Six separated factors in terms of content but overlapped in terms of experiment are known that a city is understood by them and the development of city brand can be evaluated in this way [30]. These factors are so-called "city brand index." Now, it is the time to think about the new ways to improve the city image in order to attract the tourists [31]. Cuttler et al. argued that many cities are dying or experiencing chronic depression but other cities can experience the promotion and some of the cities have continued and strong growth [21]. City branding provides a framework and tool for distinction, focus, and organization of the competitive characteristics of a city that should be rooted in the realities [32]. One of the preconditions of the success in implementing city branding is drawing a strategic plan and cooperation of all units for proper implementation of the plans and participation in citizens' community in distinct fields of city branding [33]. Currently, many metropolises in the world have acted to prepare and implement strategic planning of city branding, and these plans play a significant role in promoting their position among their competitive cities [15].

City branding is an emerging theory that emphasizes on identifying the sustainable competitive advantage of a city and converting it to a distinct competitive identity [34]. City branding distinguishes a city from other cities in the domestic, national, and global levels. It is the mission that most strategies of the cities and metropolises are formulated to fulfil it [35]. This activity is an informed attempt to create the mindset and meanings in the mind of the addressee or addresses from the city, province, state, country, region, continent, or the world [11]. Finally, the legitimacy of a brand of a city in the minds of different groups and classes of the citizens provides numerous opportunities for policymakers to create economic, political, cultural, social, tourist, communication, and commercial benefits for the city and develops an identity for a city in a range of conceptual variables like history, anthropology, economy, politics, and policies [36]. Strategic brand of the city means that the city brand should not be formed based on the old narratives of the city, but the future policy-making, policy, and strategies of the city, like the existing narratives, can have an identity forming effect for the city. It is sometimes necessary to pass the organic identity of the city and promote it to a strategic identity such that new competitive values develop with the help of city branding [37].

\subsection{A Key Issue in Organic and Strategic Approaches of City} Branding. As pointed before, city branding intends to create a distinct competitive identity and narration of features and advantages of the city in the mind of its beneficiaries. However, how to assign a distinct identity to a place in order to create the brand? In sum, how can we separate a place from its land features and change it to a word or phrase, image, and sign such that it can have meaning in a discourse, communicative language, thought, and dynamic, continuous process? Every sign system has its requirements (Figure 1). A sign system is a social system and forms during the social, civil, and historical-natural life; therefore, it cannot be created artificially or imperatively [13]. Based on this and in order to identify the constituent elements of the competitive identity, a model called benefits ladder (which is very similar to the Maslow model) was designed to develop and manage city brand [38].

According to the studies about formulating the city branding strategy, three macro factor steps will be influencing the branding that are culture, religion, demography, politics, beneficiaries, innate natural resources and media [39]. The comprehensive brand strategy is the first step to achieve these goals [40]. City branding leads to renovation and 
TABle 1: Scientific definitions of branding.

Brand definition Organization

A name, word, term, symbol, mark, mark, design, or combination of these is a specific representation of the goods and products of one or a group of manufacturers or sellers who derive those goods and services from the goods or services of other manufacturers and sellers. It distinguishes.

American Marketing Association (AMA) [20]

A name, phrase or term, sign, mark, symbol, design, or combination thereof which is intended to introduce a product or service offered by a vendor, or group of vendors, thereby distinguishing them from the products of competing companies. They build.

A design, sign, symbol, word, or combination of these is used to create an image that distinguishes a product from competitors' products.

The brand must include the objective and subjective (intangible) characteristics of a product.

A brand is a mindset or image of a specific product or service that creates a connection between the consumer and the provider.

$[23]$

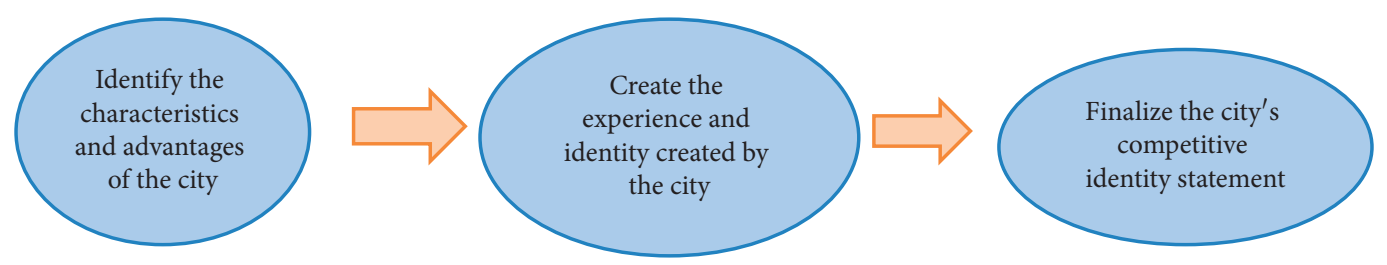

FIGURE 1: Organic and strategic approaches of city branding.

development of more opportunities for competitions among the cities, and as a result, it increases the chance of using creative and native methods to attract tourists and investors and promotes the identity of the residents in the national and local levels [41] as mentioned in Figure 2.

Currently, considering the widespread urban management in the metropolises, using tourism attractions can play an important role in introducing a city as the global tourism attraction and the economy of the cities [42]. Today, tourism industry as a dynamic industry with particular capabilities has allocated a significant part of the economic and production activities in the developed and developing countries to itself [43]. It plays an undeniable role in changing and forming the environment as a powerful tool, and it can direct the labour and economic, social, cultural, and political activities [44]. Today, tourism branding has attracted many people because of its attractions, proper infrastructures, resolving unemployment, providing employment, and urban development [45]. Generally, urban tourism is a diverse combination of different activities that form by joining the environmental features with the capability of the city in attracting the tourists and providing service for them [42]. The condition for the success of any city in the development of tourism is the presence of urban infrastructures or integration of urban management with a smart approach [46]. In recent years, the tourism industry and its economic reflections in the globalization have led to the necessity of increasing public and economic incomes [47].

\section{Research Area}

Hamadan province is located in the west of Iran with an area of $19,493 \mathrm{~km}^{2}$ and $1741 \mathrm{~m}$ height from the sea level [48]. This province is limited to Zanjan and Qazvin in the

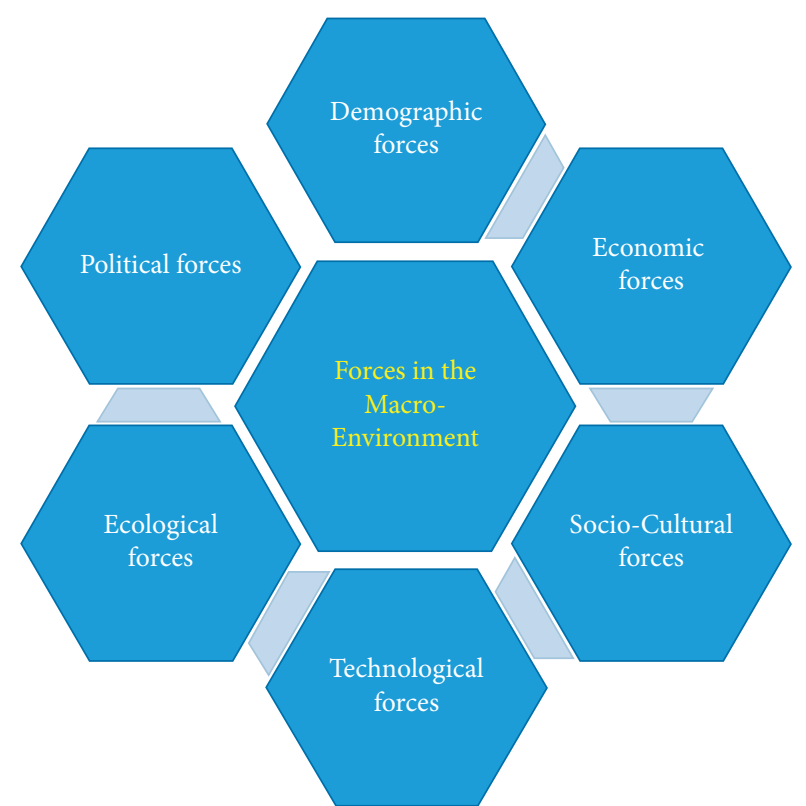

FIgURE 2: The impact of macrofactors on place branding.

north, Lorestan in the south, Markazi in the east, and Kermanshah and a part of Kurdistan in the west. The highest point in Hamadan is Alvand Mountain with $3574 \mathrm{~m}$ height, and the lowest point is the land of Amrabad along with Gharachay River in Shara and Pishkhar region. Hamadan is one of the smallest cities of the Iran, and its rank in terms of area is 23 . This province has 9 cities, 29 towns, 25 districts, and 73 rural districts (Figure 3). The capital city is Hamadan. The cities of Hamadan province are Hamadan, Nahavand, Tuyserkan, Malayer, Famenin, 


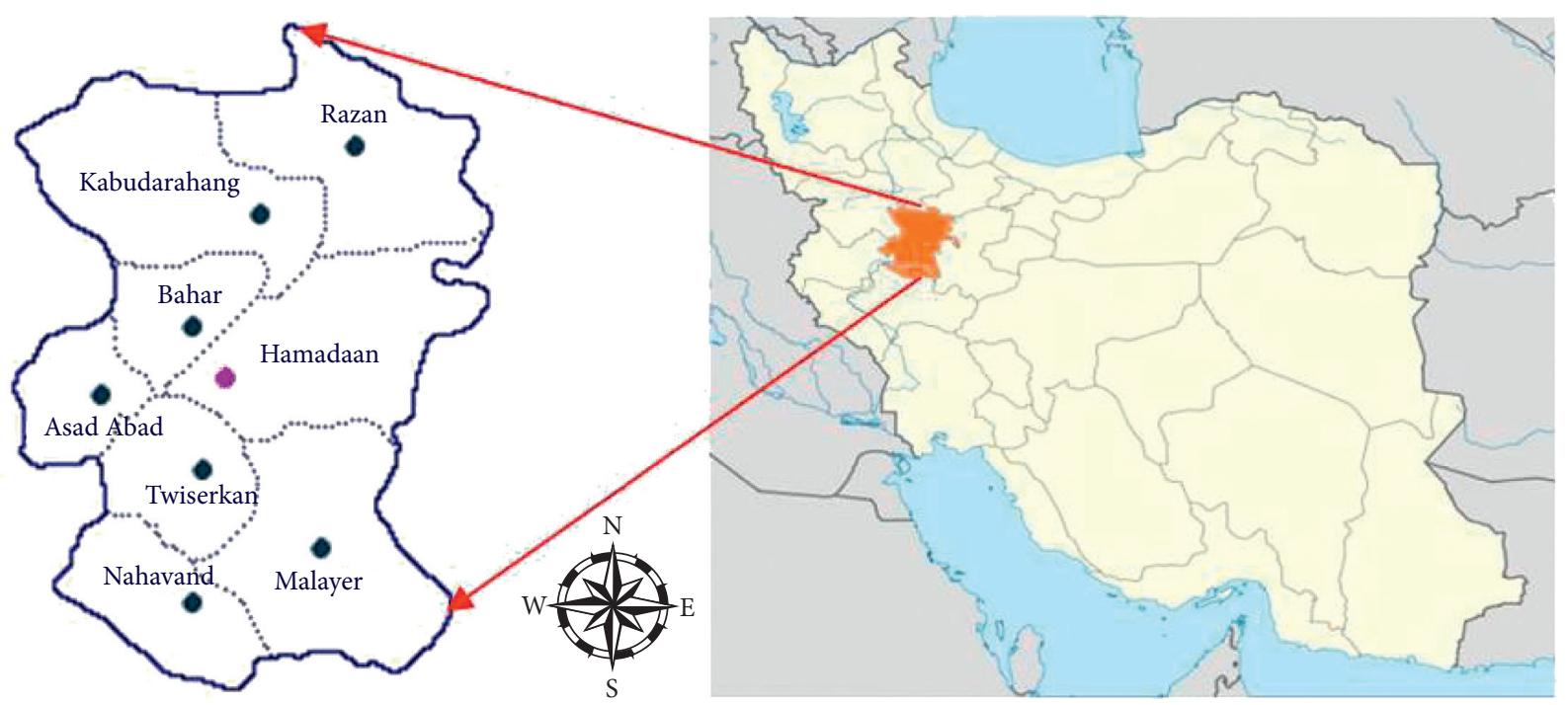

FIgURE 3: Location map of Hamadan province in the Iran.

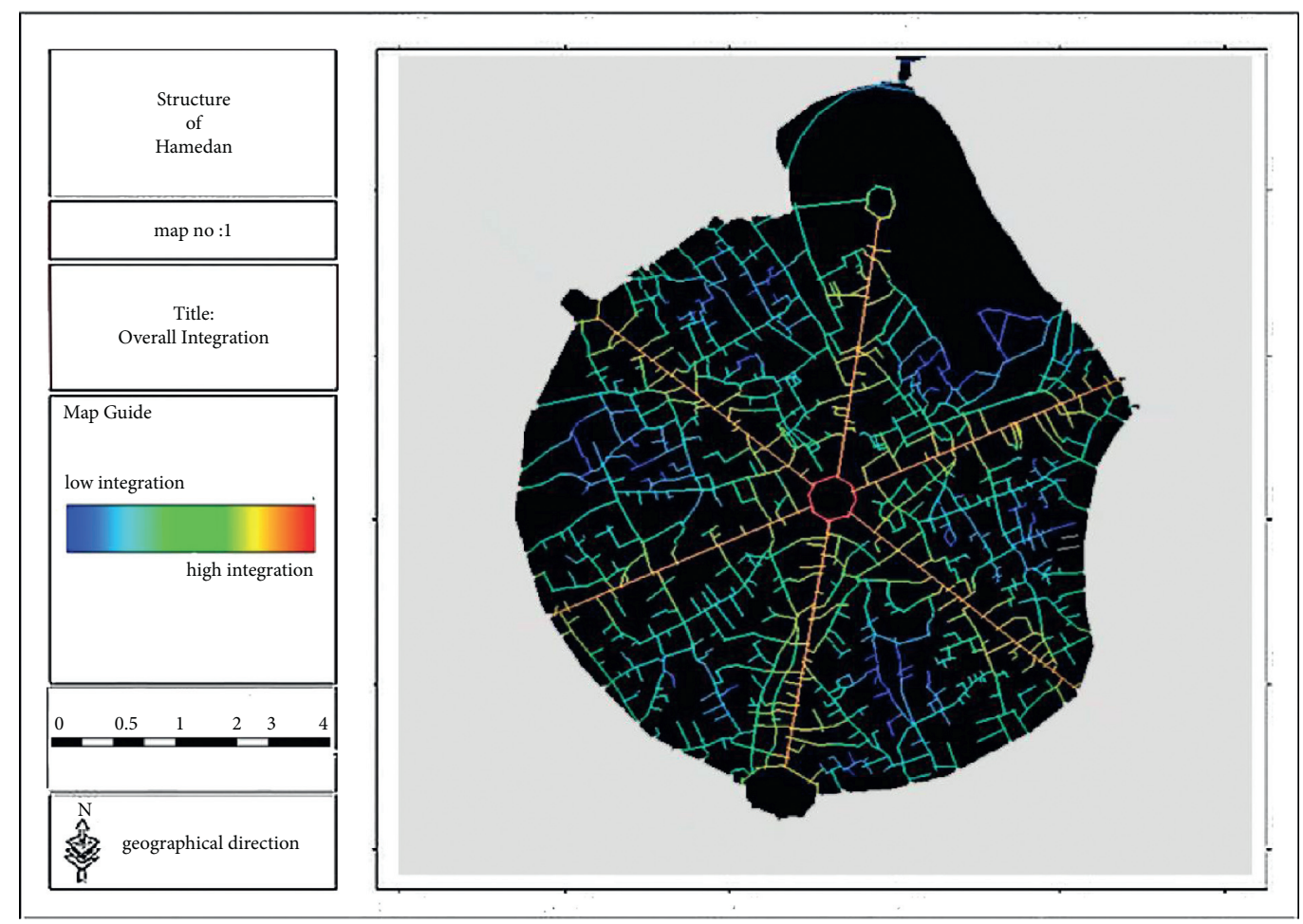

Figure 4: Map of the spatial structure of the city of Hamadan.

Kabudrahang, Asadabad, Bahar, and Razan. Hamadan city is located in the central part of the province with an area of $4084 \mathrm{~km}^{2}$ that consists $21 \%$ of the province's area [49]. In terms of population, Hamadan is the 14th densely populated city of Iran and it is introduced as one of the metropolises of Iran in August 2009 [50].

Avicenna Tomb is the symbol of the Hamadan city as well as one of the symbols of the background of Iran in the world's culture, knowledge, and science [51]. The base of the economy in this province is agriculture and animal husbandry and mining [52]. The cultivation is dry or irrigated (Figure 4). The most important mines of this province are granite, limestone, building stone, feldspar, lead, zinc, silver, chalk, limonite, silica, travertine, and iron ore $[17,49]$. There are various monuments of the Islamic period in the city including Khezr tomb, belonging to 5 th century, Alavian Dome, Esther and Mordecai Mausoleum, Qorban tower belonging to Seljuk's, Abshineh Bridge, Great Mosque, Bazaar, and square of Hamadan belonging to Safavid [53]. 


\section{Conclusion}

City brand consists of different elements including urban features, environment, politics, economy, society, and culture. These elements gather together to form the commercial brand of a city. These elements help to formulate a successful brand strategy and not only improve the sense of belonging but also increase the pride of the city. Besides, these elements provide reliability of the city. These long-term image-building actions in the city are based on the tangible and intangible elements of the city identity and help the social effects. Regarding the results of experts' questionnaire, it is necessary to develop city branding strategy as a strategy based on the culture and environment of the city in order to promote the quality of the city and sustainable development. Therefore, the result is that developing of city branding strategy is a tool to realize this goal. The undeniable relationship between tourism and the producing handcrafts, historical tourism, and old bazaar, the central square and six streets around it and finally radial and concentric city are important to consider in city branding strategy. By understanding the interaction between urban laments and its processes, the city branding strategy can be developed more. Understanding the role of city features in CDS was necessary for careful interpretation of the strategy. It is clear that planning is necessary in implementing city branding by planners and formulating of strategic plans, development of infrastructures, participation of people, support of authorities, citizenship education, financial proposals, facilitating domestic and international capitals, advertising, attracting and preserving the staff and experts, attracting tourist and visitors, and developing city branding strategy.

Indeed, implementing the brand is cumbersome and time-consuming because it includes different factors and elements that have significant effects in its formation. One of the basic steps to enter branding process for Hamadan metropolis is developing strategies for resolving the economic problems of the city, urban sociology, physical features of the city, equipment, arrangement and urban furniture, housing and construction, and proper urban planning which are not simple and possible in the shortterm. Finally, place branding and roper management for its development and expansion need different requirements that should be considered before starting the work. How Hamadan branding is done and what are its goals, reasons, tools, time, cost, and other issues are the points that should be considered at the beginning in order to avoid unpredicted problems. It should be noted that branding process for this city is a creative process that needs expertise. All considerations should be observed in branding of this city in order to provide the highest effect for tourists. Only in this case the city can achieve the successful brand and enjoys its benefits. One of the most important uses of the cities is providing new tourism services because the formation of the postmodern world with its main proposition, i.e., globalization, leads to development of information technology and tourism and a new period begins in social and cultural interactions of the human, especially in urban constructions. However, Hamadan can be a suitable place to attract domestic and international tourists.

\section{Data Availability}

The data used to support this study are available from the corresponding author upon request (n.ghanbari@ iauksh.ac.ir).

\section{Conflicts of Interest}

The author(s) declare that there are no conflicts of interest regarding the publication of this paper.

\section{References}

[1] B. Vigro and L. Chernatory, "Delfic brand visioning to align stakeholde buy-hn to the city of Birminghham brand," Brand Management, vol. 13, no. 6, pp. 379-392, 2006.

[2] D. A. Aaker, "Win the brand relevance battle and then build competitor bariers," Callifornia Mangement Review, vol. 52, no. 2, pp. 43-57, 2014.

[3] A. Insch, "Branding the city as an attractive place to live," in City Branding, pp. 8-14, Palgrave Macmillan, London, UK, 2011.

[4] G. Hankinson, "The brand images of tourism destinations: a study of the saliency of organic images," The Journal of Product and Brand Management, vol. 13, no. 1, pp. 6-14, 2004.

[5] S. Rainisto, Success Factors of Place Marketing: A Study of Place Marketing Practicees in Northern Europe and the United States Heisinki University, Doctoral Dissertation, University of Technology, Helsinki, Finland, 2003.

[6] S. Akhavan and Sharareh, Feasibility Study of Creating an Urban Brand, A Case Study of Tehran's 12th Urban District [In Persian], M.Sc. Thesis, University of Tehran, Tehran, Iran, 2010.

[7] P. Kotler, M. A. Hamlin, I. Rein, and D. H. Haider, Marketing Asian Places: Attracting Investment, Industry and Tourism to Cities, States and Nations, John Wiley \& Sons, Hoboken, NJ, USA, 2001.

[8] S. Anhoit, "The Anholt-GMI city brands index: how the world sees the world, S cities," Place Branding, vol. 2, no. 1, pp. 18-31, 2006.

[9] A. Noori and M. De Jong, "Towards credible city branding practices: how do Iran's largest cities face ecological modernization?," Sustainability, vol. 10, no. 5, p. 1354, 2018.

[10] J. Lynch and L. de Chernatony, "The power of emotion: brand communication in business-to-markets," Journal of Brand Management, vol. 11, no. 5, pp. 30-48, 2004.

[11] S. Zenker and S. C. Beckmann, "My place is not your placedifferent place brand knowledge by different target groups," Journal of Place Management and Development, vol. 6, no. 1, pp. 6-17, 2013.

[12] S. Anholt, "Competitive identity the new brand management for nations, cities and regions," Cities, vol. 19, no. 1, pp. 31-50, 2009.

[13] A. Masoudnia, Investigation and determination of the most important effective factors of urban brand in Tehran and providing appropriate solutions, Master's thesis, Payame Noor University, Faculty of Social Sciences and Economics, Tehran, Iran, 2014, (in Persian). 
[14] G. Ashworth and M. Kavaratzis, "Beyond the logo: brand management for cities," Journal of Brand Management, vol. 16, no. 8, pp. 520-531, 2009.

[15] E. U. Ulke, A Brief Histort of City Branding in Istanbul, pp. 117-130, Beykent University, Turkey, Iran, 2016, Master Thesis.

[16] O. A. Kharazmi, M. Rahnama, and N. Rahim Vaqbali, Comparative Study of Global Experiences of Urban Branding Process and Providing Solutions for the Metropolis of Mashhad, The First National Conference on Geography, Tourism, Natural Resources and Sustainable Development, Tehran, Iran, 2014.

[17] T. T. Truong, "Smart city and modelling of its unorganized flows using cell machines," Civil Engineering Journal, vol. 6, no. $5,2020$.

[18] J. H. Nada and T. W. Shireen, "Relationship of smart cities and smart tourism: an overview," High-Tech and Innovation Journal, vol. 1, no. 4, 2020.

[19] S. Zenker and N. Rütter, "Is satisfaction the key? the role of citizen satisfaction, place attachment and place brand attitude on positive citizenship behavior," Cities, vol. 38, pp. 11-17, 2014.

[20] D. Twedt, "The American Marketing Association in 1960," Journal of Marketing, vol. 25, no. 1, pp. 57-61, 1960.

[21] P. Cutler, Marketing Management, (In Persian), Translated by Bahman Forouzandeh, Amokhteh Publications, Isfahan, Iran, 2006.

[22] J. Eshuis and A. Edwards, "Branding the city, the democratic legitimacy of a new mode of governance," Urban Studies, vol. 50, no. 5, pp. 1066-1082, 2008.

[23] J. Johansson and D. Power, The Image of the City-Urban Branding as Constructed Capabhlities in Nordic City Regions, Department of Social and Economic Geography, Uppsala University, Sweden, 2007.

[24] K. Dinnie, City Branding: Theory and Cases, Springer, Berlin, Germany, 2010.

[25] A. Tiganescu, B. Grecu, and I. G. Craifaleanu, "Dynamic identification for representative building typologies: three case studies from bucharest area," Civil Engineering Journal, vol. 6 , no. 3, 2020.

[26] E. Avraham and E. Ketter, "Media strategies for marketing places in crisis: improving the image of cities, countries, and tourist destinations," Butterworth Heinemann, vol. 10, no. 8, pp. 32-40, 2008.

[27] M. Kavaratzis, "What can we learn from city marketing practice?" European Spatial Research and Policy, vol. 16, no. 1, pp. 41-58, 2009.

[28] A. Brandley, T. Hall, and M. Harrison, "Selling cities," Promoting New Images for Meeting Tourism, vol. 17, no. 19, pp. 20-32, 2008.

[29] S. Anholt, Competitive Identity of New Brand Management for Nations [In Persian], Tahan Publishers, Chennai, Tamil Nadu, 1st edition, 2013.

[30] S. Gildeh and W. Moradi, Statistical Analysis with SPSS and AMOS Software, Mazandaran University Press, Babolsar, Iran, 2nd edition, 2013.

[31] K. Hosseini, S. Hamid, and M. Rezvani, Comprehensive Brand Management Schools, Valuation and Development of the National Brand, Gisum Publications, Tehran, Iran, 2nd edition, 2013.

[32] M. Kavaratzis, From City Marketing to City Building; an Interdisciplinary Analysis with Refrence to Amesterdam, Budapest, and Athens. Phd Dissertation, Faculity of Spatial Sciences, pp. 117-205, University of Groniongen, Groniongen, Netherlands, 2008.
[33] M. Kavaratzis and G. J. Ashworth, "Partners in coffeeshops, canals and commerce: marketing the city of Amsterdam," Cities, vol. 24, no. 1, pp. 16-25, 2007.

[34] Y. Keshavarz, "Globalization and the necessity of global citizenship education," Quarterly Journal of Global Strategic Studies, vol. 6, no. 3, pp. 179-194, 2013.

[35] M. Kian, "A study of success factors in city branding: the ISE conceptual model," Journal of Chinese Marketing, pp. 58-66, 2010.

[36] M. Tarfiei, "Urban branding, a new approach in urban management, (case study of Barcelona, Spain) [in Persian]," in Proceedings of pthe Annual International Conference on Civil Engineering, Architecture and Urban Planning, Shiraz, Iran, 2015.

[37] M. Ameri, "Identifying the effective factors of urban and countr planning with strategic approach (case study of Mashhad metropolis) [in Persian]," in Proceedings of pthe 4th International Congress of New Research in Management Studies, London, UK, March 2017.

[38] A. Tiwari and S. Bose, "Place branding: a review of literature," The Journal of Sri Krishna Reserch \& Educational Consortium, vol. 4, pp. 15-24, 2013.

[39] B. D. Merrilees, D. Miller, and Herington, "Multiple stakeholders and multiple city brand meaning," European Journal of Marketing, vol. 45, no. 7-8, pp. 1032-1047, 2012.

[40] A. Mirmoinin and A. Azari, "Strategic city branding, from theory to practice," Armanshahr Archhtecture and Urban Development, vol. 11, no. 24, pp. 97-108, 2018.

[41] B. Biker, Branding Tourism Destination (Necessities for Success in Landscaping) [in Persian], Dunya Eqtesad Publications, Tehran, Iran, 2014.

[42] S. M. S. Kolbadi, H. Piri, K. Ali, and M. Mirtaheri, "Nonlinear seismic performance evaluation of flexural slotted connection using endurance time method," Shock and Vibration, vol. 2020, Article ID 8842230, 15 pages, 2020.

[43] H. Mommaas, "Cultural clusters and the post-industrial city: towards the remapping of urban cultural policy," Urban Studies, vol. 41, no. 3, pp. 507-532, 2004.

[44] S. Dabiri and H. Alimoradi, "Tourism in hamadan province in order to sustainable development," The First National Conference on New Horizons in the Capability and Sustainable Development of Architecture, [In Persian], Civil, Tourism, Energy and Urban Environment, Tehran University, Tehran, Iran, 2014.

[45] T. Namin, E. Abolfazl, and F. Mosharafi, "Prioritization of special components of brand value in tourism destination from the perspective of foreign tourists [in Persian]," Journal of Tourism Management Studies, vol. 24, 2013.

[46] H. Mohammadpour Zarandi, A. Hassani, and N. Aminian, "Factors affecting urban brand and its priorities from the perspective of international tourists (case study: Milad Tower, Tehran), [in Persian]," Quarterly Journal of Economics and Urban Management, vol. 14, 2016.

[47] A. Nehchiri, Historical Geography of Cities, [In Persian], Madrasa Publications Affiliated with the Educational Aid Publishing Office Tehran, Tehran, Iran, 1991.

[48] D. Oktay, "The quest for urban identity in the changing context of the city," Cities, vol. 19, no. 4, pp. 261-271, 2002.

[49] Statistical Yearbook of Hamadan Province, Hamadan Province Management and Planning Organization, Deputy of Statistics and Information of the Planning and Budget Organization of the Country, 2016.

[50] G. H. Qaraguzlu, Hegmataneh to Hamadan, Iqbal Publications, Tehran, Iran, [In Persian], 2013. 
[51] P. Zokaee, Quarterly Journal of People's Culture, Special for Hamadan, (In Persian), Tehran, Iran, 2008.

[52] S.-M. Seyed-Kolbadi, M. Safi, K. Ayoub, and M. Mirtaheri, "Explosive performance assessment of buried steel pipeline," Advances in Civil Engineering, vol. 2021, Article ID 6638867, 24 pages, 2021.

[53] N. Akbari, M. Malek, P. Ebrahimi, H. Haghani, and S. Aazami, "Safety culture in the maternity unit of hospitals in Ilam province, Iran: a census survey using HSOPSC tool," The Pan African Medical Journal, vol. 27, 2017. 